BULLETIN Bulletin hispanique

HISPANIQUE Université Michel de Montaigne Bordeaux

$111-2 \mid 2009$

Varia

\title{
La crítica al surrealismo en España
}

Isabel Navas Ocaña

\section{OpenEdition}

Journals

Édition électronique

URL : http://journals.openedition.org/bulletinhispanique/1030

DOI : 10.4000/bulletinhispanique.1030

ISSN : $1775-3821$

\section{Éditeur}

Presses universitaires de Bordeaux

\section{Édition imprimée}

Date de publication : 1 décembre 2009

Pagination : $551-581$

ISBN : 978-2-86781-617-8

ISSN : 0007-4640

Référence électronique

Isabel Navas Ocaña, « La crítica al surrealismo en España », Bulletin hispanique [En ligne], 111-2 | 2009, mis en ligne le 01 décembre 2012, consulté le 01 mai 2019. URL : http://journals.openedition.org/ bulletinhispanique/1030; DOI : 10.4000/bulletinhispanique.1030 


\title{
La crítica al surrealismo en España
}

\author{
Isabel Navas Ocaña \\ Universidad de Almería - Espagne
}

L'objet de cet article est d'analyser la réception critique du surréalisme dans l'Espagne des années vingt et jusquià la fin des années quatre-vingt-dix, quand commencent à apparaître des travaux sur la présence du surréalisme dans la poésie espagnole d'aprèsguerre. Les débats autour de l'existence d'une modalité proprement espagnole du surréalisme, les réticences des poètes de la génération de 27 à être assimilés à ce mouvement, les opinions de critiques aussi prestigieux que Vittorio Bodini, Paul Ilie, C. B. Morris, Jesuis García Gallego, Ramón Buckley, Joaquin Marco, etc., les rapports avec le surréalisme du mouvement "postista», de Miguel Labordeta, des poètes "novisimos", constituent quelques-uns des points abordés ici.

Este artículo pretende analizar la recepción crítica del surrealismo en España desde la década de los años veinte hasta finales de los noventa, cuando empiezan a aparecer trabajos sobre la presencia del surrealismo en la poesía española de posguerra. La discusión en torno a la existencia de una modalidad surrealista española, las reticencias de los poetas de la generación del 27 a ser adscritos a este movimiento, las opiniones de críticos tan destacados como Vittorio Bodini, Paul Ilie, C. B. Morris, Jesús García Gallego, Ramón Buckley, Joaquin Marco, etc., la relación con el surrealismo del movimiento postista, de Miguel Labordeta, de los novisimos, etc., serán algunos de los aspectos estudiados aqui.

The aim of this paper is to analyse how French Surrealism was critically received in Spain from the 30' to the 90', when the surrealist influence on Post-Civil War Spanish Poetry began to be studied. The debate around the existence of a Spanish Surrealist school, the' Generation of 27's' rejection of any link with French Surrealism, the critical opinions of Vittorio Bodini, Paul Ilie, C. B. Morris, Jesús Garcia Gallego, Ramón Buckley, and Joaquin Marco, the relations with Surrealism in the "postista" movement, Miguel Labordeta, the "novisimos" poets, etc., are some of the aspects studied here.

BHi, Tome 111, nº 2 - décembre 2009 - p. 551 à 581. 
Mots-clés : Espagne - Surréalisme - Génération de 27 - Mouvement «Postista» Poètes «Novísimos» - Avant-gardes.

$\mathrm{E}$ L PROYECTO de europeización del país, amparado por intelectuales como Ortega y D’Ors, convirtió en un primer momento a la vanguardia en su principal aliado. Se la llegó a considerar un factor de primer orden para lograr la ansiada incorporación a Europa. Por eso, adquirió un carácter constructivo, una menor agresividad antiburguesa, e incluso se ha hablado de un "paradójico tradicionalismo", es decir, una revisión de la tradición española para buscar antecedentes de las nuevas posiciones estéticas, revisión que explicaría por ejemplo el entusiasmo del 27 por Góngora (Mainer, 1975: 12-13). Además, este vanguardismo inicial tendrá en las teorías orteguianas sobre la deshumanización su principal punto de referencia (Soria Olmedo, 1988: 133-189). Y no hay que olvidar que Ortega en La deshumanización del arte (1925), al precisar las claves del «arte nuevo»-impopular, de minorías, intrascendente, lúdico, deshumanizado-, utiliza como constante término de oposición el romanticismo, que para él es sinónimo de humanidad, realismo, trascendencia y popularidad. De ahí que muy pronto nuestros vanguardistas se arroguen la condición de clásicos. Por ejemplo, en «La nueva lírica» (1919), Rafael Cansinos Asséns tilda ya de clásicos a los creacionistas, a los que llama «nuevos caballeros del parnaso». Y en el célebre Literaturas europeas de vanguardia (1925), Guillermo de Torre emplea de forma muy gráfica la expresión "clasicismo de lo moderno» (1925: 26). La «liquidación del romanticismo» es, en definitiva, para la crítica de la época «una de las mayores conquistas de la lírica» (Geist, 1980: 152-153). Así lo indica Enrique Salazar y Chapela, que en la encuesta sobre la vanguardia publicada por La Gaceta Literaria en 1930 elogia el impulso salutífero de los «ismos» al abrir «las ventanas de algún rezagado garito romántico» (1930: 3). Se inicia de esta forma un debate entre clasicismo y romanticismo, que he analizado por extenso en otro lugar (1996b) y que va a tener consecuencias inmediatas en la recepción crítica del surrealismo en nuestro país. De hecho, las tesis surrealistas, por su entronque romántico -confesado abiertamente por Breton en el segundo manifiesto ${ }^{1}$-, no contarán con el beneplácito de críticos como Fernando Vela (1924), Enrique Díez Canedo (1925),

1. «(...) para el romanticismo, tener cien años de existencia equivale a la juventud (...) de un ser que ahora comienza a dar a conocer sus deseos a través de nosotros» (1969: 197). 
Benjamín Jarnés (1926), etc. (García Gallego, 1984: 30-65). Por otra parte, Ortega y Gasset, al dictaminar el intelectualismo del arte deshumanizado, hizo una pequeña observación sobre el subconsciente, que resultó a la larga una consigna asumida por la crítica a la hora de enfrentarse a la escritura automática: «El arte no puede consistir en el contagio psíquico, porque éste es un fenómeno inconsciente y el arte ha de ser todo plena claridad, mediodía de intelección» (apud García Gallego, ibid.: 30).

A estas circunstancias habría que añadir la «mala prensa» que el surrealismo tuvo en España (García de la Concha, 1982: 9) no sólo por cuestiones estéticas (automatismo, neorromanticismo, etc.), sino también desde un punto de vista moral. Particularmente significativos resultan los artículos de Ernesto Giménez Caballero (1930, 1931a, 1931b, 1931c), Eugenio Montes (1930) y Sebastián Gasch (1927) en La Gaceta Literaria, porque en ellos el surrealismo es sinónimo de amoralidad y de decadencia de las costumbres (García Gallego, 1984: 77-113). Estos artículos se inscriben ya en un período -la década de los años treinta- en el que el vanguardismo basado en el cubismo y en la poesía pura, dominante hasta esa fecha, da paso a un «nuevo empuje vitalista que se ampara en la resurrección del futurismo (Giménez Caballero) y en el surrealismo francés, y que se dirige de un modo cada vez más franco hacia el compromiso moral y la acción política» (Soria Olmedo, 1988: 263-264). De ese nuevo vitalismo es responsable en gran medida la tensa situación política y social que vive el país durante la II República. Pues bien, desde las nuevas posiciones rehumanizadoras y comprometidas la vanguardia en general será tildada con frecuencia de esteticismo por intelectuales de uno y otro bando: Ramiro Ledesma Ramos, Juan Aparicio, César M. Arconada (Navas Ocaña, 1995: 23). Y se la identificará por ello inmediatamente con conductas transgresoras del orden moral tradicional: recuérdese, por ejemplo, la acusación de homosexualidad hecha por Ramiro Ledesma Ramos en la encuesta sobre la vanguardia de La Gaceta Literaria, acusación que reaparecerá en algunos textos de Escorial y Juventud (Navas Ocaña, ibid.: 56).

A partir de 1927 se produce el acercamiento de los poetas del 27 al surrealismo. Sobre los ángeles de Alberti, Poeta en Nueva York de Lorca, Pasión de la tierra, Espadas como labios y La destrucción o el amor de Aleixandre, Un rio, un amor de Cernuda, etc., son obras -escritas en estas fechasdirectamente emparentadas con la estética surrealista. Y, sin embargo, casi todos ellos, a excepción de Cernuda, se empeñaron en negar su adscripción al movimiento surrealista. Lorca, por ejemplo, a pesar de reconocer que la «emoción pura, descarnada, desligada del control lógico» está en el origen de sus poemas, puntualiza en seguida: «pero, ¡ojo! ¡ojo!, con una tremenda 
lógica poética. No es surrealismo, ¡ojo!, la conciencia más clara los ilumina». Y Rafael Alberti niega su conocimiento de las teorías francesas y justifica el parecido que algunos de sus poemas tienen con ellas gracias al surrealismo existente en la tradición popular española (1933: 14-15)². Pero será Dámaso Alonso quien dedique mayores esfuerzos al tema, sobre todo a propósito de la poesía de Vicente Aleixandre. Ya en 1932, en su reseña de Espadas como labios, Dámaso Alonso hablaba de una corriente neorromántica general -«hiperrealismo»- de la que el surrealismo francés sería sólo un subgrupo ${ }^{3}$. $\mathrm{Su}$ objetivo estaba claro: negar el influjo francés sobre los poetas surrealistas españoles. Por otra parte, dudaba de la existencia de un automatismo puro. En su opinión, siempre había una posterior "fase selectiva» ${ }^{4}$. Y Aleixandre no era en este sentido una excepción. Tres años después, y a propósito de $L a$ destrucción o el amor, volverá a insistir en este hecho ${ }^{5}$. Por todo esto concluye que no es correcta la traducción espańola del término surréalisme porque con ella se denomina una modalidad de ese neorromanticismo general o hiperrealismo que es completamente independiente de su homóloga francesa. Además, la escritura automática es una utopía. Dámaso Alonso define así los pilares de futuros acercamientos al tema: no se trata de surrealismo sino de neorromanticismo y no hay escritura automática. En cuanto a esta última cuestión, es muy importante constatar que esa ausencia de automatismo atañe tanto a la variante española como a la francesa. Según Dámaso Alonso, no es una característica exclusiva de España, como lo sería para la crítica posterior.

Todavía en los años treinta, Pedro Salinas utilizará todos estos conceptos de forma muy particular: hablará de neorromanticismo en lugar de surrealismo pero ahora para el caso concreto de Aleixandre, y justificará

2. Las declaraciones de Cernuda, Lorca, Alberti o Aleixandre sobre el surrealismo son suficientemente conocidas y han sido citadas una y otra vez por la crítica. Yo misma las he incluido en Vanguardias y crítica literaria en los años cuarenta. El grupo de Escorial y la "Juventud Creadora" (1995: 13-25). A este trabajo remito.

3. "Cuando se haga la historia de nuestro período creo que ha de resultar claro que la palabra superrealismo (surréalisme) conviene a muchas otras manifestaciones de la literatura actual. Para evitar la posible confusión llamo "hiperrealismo" a esta tendencia general contemporánea, dentro de la cual el "superrealismo" sería sólo un subgrupo» (1932: 286).

4. «(...)en la práctica no cabe duda de la existencia de una fase selectiva, en la que la razón elimina los elementos menos expresivos, aunque sin obligar al manantial poético a seguir un cauce lógico» (Ibid:: 288).

5. «La poesía de Aleixandre, como toda aquella parte de la moderna que está más o menos emparentada con el surréalisme francés y su pretendido automatismo, vuelve por fuerza a buscar el descansadero de la forma. Entiéndase bien: de una forma que, repito, nada tiene que ver con la forma clásica, sino de una forma vital, individual e individualizante, necesaria para hacer resaltar superficialmente la profunda unidad del poema» (1935: 305). 


\section{LA CRÍTICA AL SURREALISMO EN ESPAÑA}

este juicio por la falta de escritura automática. Lo que ya apuntaba en los textos de Dámaso Alonso aparece ahora perfectamente formulado en el de Salinas ${ }^{6}$. Su postura es más intransigente que la de su compañero. Con él, surrealismo y neorromanticismo, que en Alonso eran conceptos compatibles, se convierten en contrarios: Aleixandre es un neorromántico pero para no ser surrealista, es un neorromántico "por oposición a». $Y$ en el tema del automatismo también se da un paso más adelante: si para Dámaso éste era un imposible, para Salinas será un imposible en la poesía aleixandrina. De las conjunciones de estos tres pilares básicos -neorromanticismo, surrealismo, automatismo- arrancan las distintas teorías que la crítica ha venido sosteniendo sobre el tema desde entonces. Tanto Dámaso Alonso como Pedro Salinas están hablando ahora no desde los presupuestos teóricos de la deshumanización orteguiana, sino desde ese nuevo vitalismo que había empezado a cobrar fuerza en los inicios de la década de los treinta. La intención de ambos es proclamar el neorromanticismo de Aleixandre. Es más, Dámaso Alonso no parece distinguir, en un principio, el surrealismo de esa corriente neorromántica general que denomina "hiperrealismo». No es éste el caso, sin embargo, de Pedro Salinas, que comienza ya a delimitar claramente la estética neorromántica y la surrealista a partir de la cuestión del automatismo.

6. «Hasta ahora en este somero repaso de temas, nos hemos tropezado con la visión del mundo y de la sensibilidad romántica frecuentemente. Cabría calificar a Aleixandre como poeta inscrito dentro del círculo neorromántico, cada día más poderoso, de la poesía moderna. Pero si volvemos ahora a estudiar su lenguaje, su expresión poética, nos hallaremos en tangencia con otra escuela muy de hoy: el superrealismo. No hay en eso contradicción ni mera superposición accidental. En cierto modo, el superrealismo, o las escuelas afines que desde hace veinte años bullen en las letras, podrían tomarse como una consecuencia extrema, desmesurada de lo romántico. Así como la razón era la enemiga de los románticos, la gran heroína clásica con que luchaban, la lógica era la bestia negra del superrealismo, cuyo esfuerzo se concentra en sofocarla, en ensordecer ante su voz y atender a otras oscuras y profundas. Aleixandre no es un poeta superrealista. Ha pasado junto a esta escuela, y en su lengua poética adopta decididamente y con una brillantez y acierto no superados en español, ni acaso en otros idiomas, todas las libertades ofrecidas por esta escuela. Pero hay en su poesía una lógica interna que se soterra a veces, dando la impresión de incoherencia absoluta, aunque no puede engańar. La liberación de la lógica, el abandono del poeta al dictado de lo inconsciente, que existe sin duda en este libro a trechos, no pasa de un plano subordinado, no afecta a la génesis del poema, no es sistema. El poema es siempre fiel a su arranque, a su idea, a lo que vemos nacer, ya con el título muchas veces... Pero hay una impresión final unitaria del poema, y se percibe que a través de las licencias y escapadas de la lógica que el poeta se permite, la idea poética no deja de dominar el conjunto» (1935: 210). 
La crítica de Pedro Salinas nos parece, por este motivo, especialmente significativa, teniendo en cuenta que el "neorromanticismo» de posguerra - de la mano de críticos como Antonio González de Lama- va a emplear estos mismos argumentos para rechazar la relación de Aleixandre con el surrealismo.

Lo cierto es que, a pesar del vitalismo implícito en las tesis de Salinas y Dámaso Alonso, los presupuestos teóricos del arte puro siguen siendo un obstáculo importante para la aceptación plena del surrealismo, y en particular, de la "poesía antipoética» propugnada por los surrealistas. De ahí que la principal objeción de ambos se centre en el automatismo y, en contrapartida, pretendan demostrar la lógica interna y la concepción unitaria de los poemas aleixandrinos para salvar así su condición de «poéticos». Ahora, a la altura de 1935, ya no se objeta al surrealismo que sea una tendencia de tipo romántico -crítica muy frecuente en fechas anteriores-, puesto que una nueva corriente vitalista -fruto de la grave situación social y política española, a las puertas de la guerra civil- ha desbancado la hegemonía mantenida por las teorías deshumanizadoras de Ortega durante la década de los veinte. Sin embargo, esas teorías siguen, en cierta forma, funcionando como referente y, a nuestro juicio, son las responsables de la negación del automatismo por parte de los poetas del 27. De ahí, la insistencia de Lorca en la «tremenda lógica» de sus poemas, las reticencias de Dámaso Alonso sobre el automatismo o las tesis de Salinas sobre la concepción unitaria de los poemas aleixandrinos. Una generación que había elevado la poesía al rango más alto de la escala literaria no podía renunciar tan fácilmente, o al menos no podía hacerlo desde el punto de vista teórico, a las prerrogativas que convertían en "poéticas» sus creaciones y era incapaz de adherirse sin ambages a una poesía, la surrealista, que relegaba al poeta a la función de mero transcriptor del dictado del subconsciente (Cano Ballesta, 1972). Se admitió entonces el componente rehumanizador y neorromántico -así lo demuestran los artículos de Dámaso Alonso y de Pedro Salinas y aún más, los libros de Aleixandre, Lorca o Alberti, etc.-, pero hay evidentes reticencias para traspasar el umbral de lo estrictamente estético, es decir, para admitir, al menos de forma teórica, el paso hacia el automatismo surrealista. El término «neorromanticismo», utilizado por Salinas y Dámaso Alonso, es muy significativo: con él se intenta desvincular del surrealismo francés la nueva poesía irracionalista y vitalista de Aleixandre.

Pero no escaparía tampoco en este momento la poesía aleixandrina de un reproche -la deshumanización-, lógico si se tiene en cuenta ese nuevo vitalismo al que vengo aludiendo. Hubo críticos, como Ángel del Río, que, a 


\section{LA CRÍTICA AL SURREALISMO EN ESPAÑA}

diferencia de Dámaso Alonso o de Salinas, no vieron en el surrealismo ningún indicio de las nuevas posiciones rehumanizadoras. Por eso, en una reseña sobre Pasión de la tierra, después de afirmar que la poesía aleixandrina «es ya poesía surrealista franca, de un surrealismo mucho más específico que el de ningún otro de los poetas españoles actuales», Del Río puntualiza: «Seguimos, por tanto, dentro de un ciclo de deshumanización, no por la supresión de los sentimientos humanos más comunes como era norma en el arte de hace unos años sino precisamente por la exageración desrealizadora de lo más humano, casi de lo animal: del instinto, de la pasión, de la sangre...» (1935: 22) ${ }^{7}$.

De todas formas, durante los años cuarenta domina la posición de Salinas, que será desarrollada entre otros por Antonio González de Lama, Ricardo Gullón o el propio Dámaso Alonso, con la fórmula siguiente: frente a la luz neorromántica de Sombra del paraiso -léase diafanidad lógica, cuidado de la forma, etc.-, la oscuridad surrealista -léase escritura

7. Pero será Ortega y Gasset, en La deshumanización del arte, quien siente las bases de esta identificación entre surrealismo y deshumanización: «Éste es el nexo latente que une las maneras de arte nuevo en apariencia más distantes. Un mismo instinto de fuga y evasión de lo real satisface en el suprarrealismo de la metáfora y en lo que cabe llamar infrarrealismo. A la ascensión poética puede sustituirle una inmersión bajo el nivel de la perspectiva natural. Los mejores ejemplos de cómo por extremar el realismo se le supera -no más que con atender lupa en mano a lo microscópico de la vida- son Proust, Ramón Gómez de la Serna, Joyce» (1925: 46).

José Díaz Fernández también alude a esta problemática en El nuevo romanticismo: «Porque lo humano no es dejar suelto el impulso biológico, ni lo humano consiste en desatar la personalidad de sus vinculaciones interiores. Lo humano es mejor que nada la acción espiritual del hombre, su contacto permanente con el futuro que no es patrimonio de nadie» (1930: 45).

Ya en la posguerra, Antonio González de Lama fundamentará su crítica al surrealismo en un marcado desacuerdo con el materialismo, con la burda biología que acarrea, en su opinión, el aprovechamiento de la subconsciencia: «He aquí por qué recusamos un cierto subrealismo que, por huir de zonas claras y remansos conscientes, se sumerge en honduras infrahumanas de neto carácter biológico. Y sale del buceo con las manos enlodadas y en la voz un tono amargo de cloaca» (1946: 457).Y en 1949, José Luis Aranguren, embarcado en la aventura "totalizadora» de su grupo con los espadañistas, censurará también la obsesión surrealista por lo subconsciente acusándola de deshumanización: «Al pronto nos sentimos tentados de hacer una excepción con el superrealismo que, diríase, supone un acercamiento a la vida. En su tendencia tal vez sea efectivamente así, pero la verdad es que la introducción del concepto mítico, cuando no simplemente automático o pueril, de lo "subconsciente" tiene todavía muy poco de "rehumanización del arte". Lo que hay por debajo de mí mismo, aquello que está en mí pero que no puedo descifrar sin una clave traída de fuera, aquello que en realidad no soy, porque no puedo responder de ello y dar cuenta contándolo, será, si se quiere, subconsciencia, pero no es todavía existencia». 
automática- de los libros anteriores a la guerra civil, y en concreto de Pasión de la tierra. Este último poemario se reeditó en 1946, dos años después de la aparición de Sombra del paraíso, y fue el desencadenante de una reflexión por parte de la crítica poética de la época sobre el papel del surrealismo en la poesía de Vicente Aleixandre. Dos críticos destacan en este sentido: Ricardo Gullón y Antonio González de Lama. Los dos coinciden en considerar la huella del surrealismo simplemente como una etapa transitoria, a la que pertenecería Pasión de la tierra, pronto superada por la claridad y el orden neorrománticos de Sombra del paraiso. Por eso, según Lama, "En Pasión de la tierra está, sí, el punto de arranque; pero en la poesía posterior hay más, mucho más de lo que este libro primordial apuntaba. "El camino hacia la luz" estaba aún sin descubrir; hoy el poeta ha caminado por él hasta la cima luminosa» (1947: 560). Y Gullón puntualiza: «(...) en Sombra del paraiso supera Aleixandre la desesperación, como deja atrás también su fase de oscuridad: el mundo cruelísimo y revuelto de Pasión de la tierra fue ordenado y clarificado" (1946: 131). Y todo ello «sin que a través de los diversos avatares vividos por la poesía de Vicente Aleixandre se haya perdido aquel enérgico arrebato de los comienzos» (Ibid.). Ese arrebato al que se refiere Gullón es el «hervor de humanidad elemental y oscura» del que habla González de Lama (1947: 560). Los dos aprecian, en suma, el impulso rehumanizador que el surrealismo aportó a la poesía de Aleixandre. La humanidad de Pasión de la tierra se mantiene intacta en la trayectoria ulterior del poeta, ahora bien esa humanidad levanta el vuelo tras el abandono de la oscuridad surrealista hacia la luz de Sombra del paraiso. La dialéctica Luz/OsCuRIDAD -en relación siempre con la metáfora de las aguas subterráneas- tendrá gran fortuna en la crítica de los años cuarenta para aludir al movimiento surrealista. Basta recordar los artículos de Oswaldo P. Lira, en donde se advertía a los poetas sobre "el peligro de caer y enfangarse en el oscuro abismo de la subconsciencia» (1944: 410; Navas Ocaña, 1995: 65-72) o el texto de José García Nieto en la revista Juventud, exigiendo a la poesía «amor, vitalidad y masculinidad (...) frente a cualquier vestigio suprarreal de cenagosos fondos freudianos» (1942: 2; Navas Ocaña, 1995: 179-180). Esta dialéctica es muy frecuente en las reseñas sobre la poesía de Aleixandre. Por ejemplo, en la que Dámaso Alonso publica en El Español a propósito de Sombra del paraíso se define la evolución de Aleixandre como un proceso que va «desde lo turbio hasta la más lavada limpidez». Y la emplearán igualmente otros críticos como R. Benítez Clarós, para quien «la diafanidad lógica» constituye la más importante cualidad de Sombra del paraíso en relación a poemarios 
anteriores (1944: 269). Lo mismo dirán, aunque ya en 1950, Leopoldo de Luis $^{8}$ e Ildefonso Manuel Gil ${ }^{9}$, al ocuparse de Ámbito y Mundo a solas.

Por otra parte, Ventura Doreste, en un artículo titulado significativamente «La unidad poética de Aleixandre» (1950), señala que Ámbito es anticipo tanto de "los libros superrealistas» como de Sombra del paraiso, es decir, de «la atracción inevitable hacia el caos» y del «universo luminoso». No parece, por tanto, que Doreste esté hablando de un proceso evolutivo en el que el caos y la oscuridad surrealistas hayan ido desapareciendo de forma gradual en favor de la luz paradisíaca, sino de dos líneas que discurren paralelas desde los comienzos y que, por ello, constituyen «la unidad poética de Aleixandre». Este planteamiento resulta novedoso a tenor del acuerdo general -ya analizado- que por estos años existe en la crítica respecto a la división en dos etapas de la poesía aleixandrina: la surrealista, antes de la guerra, y la neorromántica, inmediatamente después. Con esta nueva perspectiva lo que se sanciona finalmente es una concepción de la generación del 27 que ha gozado de gran predicamento hasta hoy: la doble atracción por la tradición y la vanguardia. Esta concepción tiene su origen en el modelo neorromántico, empeñado en considerar la producción de posguerra más tradicional, menos arriesgada y, por tanto, superadora de los ideales vanguardistas anteriores. Después de la férrea disciplina garcilasista, un leve soplo de libertad quiso colarse en nuestras letras y lo hizo pagando el precio de la constante conciliación: lo neorromántico es también clásico ${ }^{10}$, lo vanguardista no

8. Según Leopoldo de Luis, en Pasión de la tierra, Espadas como labios y La destrucción o el amor «el poeta (...) ha creado un mundo extraordinario, mágico, caótico, en el que apasionadamente intervienen las fuerzas vitales en una concepción unitaria y cósmica. Ha empleado para ello un material onírico y peculiarmente surrealista. Luego se ha clarificado, ordenado todo ese mundo, y ha creado la prodigiosa visión de Sombra del paraíso» (1950: 2).

9. «Cuando en 1945 apareció Sombra del paraiso, todos tuvimos la impresión de que en el reducido ámbito de nuestra poesía actual se había producido un acontecimiento de primera magnitud. En aquellos magníficos poemas, Aleixandre parecía abandonar sus anteriores nebulosas - ¿atormentadas?, ¿frías?- y se adentraba en los caminos abiertos y luminosos de una difícil y bella claridad poética. Lo cual no nos sorprendió a cuantos pensábamos que el surrealismo de sus libros anteriores era ya, por muchas razones, insostenible» (1950: 587).

10. Y de nuevo es la poesía de Aleixandre la que mejor nos sirve para ejemplificar esta posición. González de Lama dirá de ella: «Si Ámbito es clásico, y Espadas como labios es romántico, y La destrucción o el amor romántico represado, Sombra del paraíso está en la misma línea de La destrucción o el amor, pero más contenido aún, menos arrebatado. Y más perfecto, más acabado, más afilado. Sin la frialdad lapidaria del primer libro, sino con una perfección más conmovida, más agitada por un violento hervor que se alisa y remansa en la tersura resplandeciente de la forma. Es difícil alcanzar una nitidez tan esplendorosa sin perder un ápice de pasión, de fuerza, de humanidad vibrante y tremante» (1944: 63). Y Dámaso Alonso también observa en Sombra del paraiso un importante componente romántico que sin 
resulta peligroso porque, además de pertenecer al pasado, ha sido sólo una valiosa contribución, una estación obligada hacia la conversión final-siempre de signo tradicional y clásico (Alonso, 1943; Navas Ocańa, 1995: 86-92). Desde aquí, no parece difícil dar un paso más para unificar vanguardia y tradición, tal como hace Doreste en 1950, sobre todo cuando el componente vanguardista ya había sido despojado por críticos como Lama o Dámaso Alonso de su faz más temible, más revolucionaria, y además ambos habían esbozado esa posibilidad de unión a propósito de Gerardo Diego ${ }^{11}$. Así surgió un tópico hoy perfectamente establecido a la hora de estudiar la generación del 27: la alianza de tradición y vanguardia (Navas Ocaña, 1996c). El propio Gerardo Diego coincidirá con sus compañeros de generación en desvincular la poesía aleixandrina del automatismo surrealista con el argumento de la vigilancia racional y consciente, de la atención a la forma. Ahora bien, a diferencia de Dámaso Alonso o de González de Lama, y más en la línea de Salinas, Diego ni siquiere admite la presencia del surrealismo en Pasión de la tierra. También en este poemario hay, según Diego, vigilancia racional ${ }^{12}$.

embargo contiene, modera una perfección formal emparentada con nuestros clásicos y con Mallarmé: «Todos hemos llamado romántica a la poesía de Aleixandre. ¿Servirán todavía para algo estas palabras? Si para algo sirvieran yo diría que Sombra del paraíso es poesía romántica aún por el empuje y la abundancia del manantial, por el anhelo total que la inspira. Mas también hay contradictorios misterios en los caminos de la belleza. Libérrimo sigue siendo el verso, pero ¡cuán bellamente ha fraguado en cada una de sus unidades! El mundo en fusión ha ido a aquietarse en expresiones que, palpitantes aún, tienen ya la perennidad de los mármoles más bellos. ¡Quién lo pensaría del autor de Espadas como labios! Sombra del paraíso ha alcanzado el límite de la hermosura posible en la palabra humana, como cuando más se haya rozado tal meta en el esfuerzo del Renacimiento, o en el de los neoclásicos, o en el del Parnaso, o en la línea que lleva a Mallarmé. ¡Bella piedra deslumbradora, bella, abrasada y fría, como tallada por un dios esta Sombra del paraíso, en la que Vicente Aleixandre, una triste tarde del mundo, se encontró definitivamente con la belleza!» (1944).

11. Para Dámaso Alonso, las dos facetas (tradicional y vanguardista) de Gerardo Diego tienen el mismo origen: «Pero el poeta sabe adónde quiere ir, y que se trata de dos caños de un mismo manantial. A un lado los Versos humanos, a otro, Imagen y Manual de espumas. Mas lo mismo el verso tradicional que el puro experimento lírico, brotan humanamente del corazón, son voces diversas de una sola y total armonía» (1943: 121). Y González de Lama apostilla al respecto: «Se ha hablado mucho -el mismo poeta habla de ello a menudo- de un Gerardo Diego partido en dos, de un poeta de doble faz, mirando al pasado, a la tradición y lanzándose por entre las zarzas de los caminos nuevos. Es el mismo caso de Góngora con la diferencia de que en Gerardo Diego aparece la dualidad desde sus primeros pasos. Sin embargo, lo mismo que Dámaso Alonso demostró la irrealidad de este dualismo en Góngora, también podría demostrarse cómo en Gerardo Diego los dos caminos son sólo uno» (1944: 111; Navas Ocańa, 1997a: 133-143).

12. «Suele hablarse a propósito de la etapa poética que en este libro se inicia, de "Sobrerrealismo". Sólo con precisas reservas puede admitirse. Nada en estas prosas, como 


\section{LA CRÍTICA AL SURREALISMO EN ESPAÑA}

Por lo demás, Diego coincide con lo que Dámaso Alonso venía planteando desde 1932. En "La última poesía española», artículo publicado en Arbor en 1947, afirma: «El último proceso revolucionario se produjo hacia 1929, y fue, más que influencia, coincidencia española con rasgos bien genuinos de la angustiosa anarquía sobrerrealista» $(1947: 419)^{13}$.

En este período Dámaso Alonso participa de la tesis de Gullón y Lama -así lo demuestra su artículo sobre Sombra del paraíso (1944)-, que, si bien se mira, no resulta tan contraria a la que él formula en los años treinta. De hecho, en ella se halla el origen de esta otra. Dámaso Alonso no ha tenido que hacer ningún esfuerzo para aceptarla, porque a la postre se trata de seguir hablando de neorromanticismo y no de surrealismo, y de negar la escritura automática. Pero el término surrealismo termina por imponerse. No se olvide que los franceses, al constituirse en un movimiento organizado de amplísima repercusión internacional, dieron, por así decirlo, «el nombre a la cosa». En 1949, Dámaso Alonso, no sin hacer patente su desacuerdo y su queja, decide resignadamente aceptarlo para el caso de España. Es entonces cuando por primera vez hablará de «surrealismo español», aunque lo hará en una nota a pie de página y de forma marginal al tema que está tratando ${ }^{14}$. Un año después, en su discurso de contestación a Vicente Aleixandre con

en los posteriores versos, de simulación, de frivolidad literaria, de "escuela" o prejuicio programático de onirismo y automatismo. Son poemas que brotan como sangre, como total espontaneidad, pero sometida siempre, siempre vigilada por una acomodación previa de la inteligencia rectora, por una "registración" adecuada del órgano estético, con un seguro instinto, pero instinto de artista, para adivinar desde la fuente la distancia y los contornos del delta de la desembocadura» (1944: 181-182).

13. Jorge Guillén es de la misma opinión: «los jóvenes poetas españoles no tuvieron relación personal con aquellos coetáneos franceses... Casi, casi no era necesario leer para estar enterado del superrealismo. Bastaba respirar el aire de época. Es otro rasgo de nuestro siglo XX: la insinuación de cultura fatalmente respirada» (1970: 205). Y otro tanto dirá Guillermo de Torre: «Por lo pronto, ninguno de los poetas que suelen citarse como influidos o seguidores del superrealismo tuvo contacto con los representantes iniciales de aquel movimiento: Breton, Aragon, Soupault, Tzara. Aún aseguraría más: ninguno de los sedicentes superrealistas de España -al contrario de algunos ultraístas- manifestó un conocimiento directo y suficiente de teorías, ni colaboró en sus revistas ni hizo el menor acto público de adhesión o afinidad. Cuando más, les llegarían reflejos -a través de comentarios y transcripciones hechas por otros, entre los cuales, y no es jactancia, pues no hay por qué, debo contarme yo en primer término-, sin considerar el eco escandaloso de las anécdotas pintorescas» (1965: 572).

14. "Digo "lamentablemente" porque da pena emplear un extranjerismo (que en seguida sugiere dónde se debió originar el movimiento) cuando creo que el llamado "surrealismo" español tiene raíces autóctonas, cuyo desarrollo posterior se ve favorecido por el movimiento francés. Lo mismo ocurre ahora con esa peste de "existencialismo". (...) Por lo visto, españoles e hispanoamericanos tenemos la firme creencia de que siempre es menester que alguien nos colonice: ¡estamos aviados!» (1949: 707). 
motivo del ingreso de éste en la Real Academia Española, volverá a mostrar no sin disgusto su consentimiento ${ }^{15}$. Por otra parte, fiel a sus convicciones iniciales, no sólo afirma el carácter selectivo y elaborado de las imágenes aleixandrinas sino que ni siquiera se plantea ni menciona la cuestión del automatismo. Dejaba así la puerta abierta para que futuros investigadores hablasen de una modalidad surrealista espańola cuya principal peculiaridad radica en la ausencia de escritura automática, tal como hará Paul Ilie en 1968 en Los surrealistas españoles. Pero Ilie contó con otros precedentes: por ejemplo, los de José Luis Cano, Carlos Bousoño, Manuel Durán, José Albi y Joan Fuster.

A pesar de su disconformidad con el automatismo, expresada en textos como el publicado en Corcel, con ocasión del homenaje a Vicente Aleixandre ${ }^{16}$, José Luis Cano ha sido uno de los críticos que se han ocupado del surrealismo con cierta asiduidad. En fecha temprana, en 1946, dedicó un artículo a conmemorar el centenario de Lautréamont, recordando el estrecho vínculo entre los surrealistas y este escritor (1946). Y en 1950, publica en Arbor una breve, aunque muy interesante, «Noticia retrospectica

15. «Me fastidia tener que emplear la palabra superrealismo: ya no hay más remedio que hacerlo. Vamos interpretando la historia de España y de su literatura siempre a la zaga de algo que venga de fuera. Cuando lo nuestro no se conforma bien con el nombre extraño lo metemos de un empujón en el molde que nos llega. (...) Así se echó mano del surréalisme francés, y se tradujo la palabra, para que fuera marbete de cosas españolas. Porque la imagen onírica, característica del surréalisme, existe ya, claro que con rasgos muy peculiares, en el Lorca de las Canciones escritas de 1921 a 1924, y el libro de poemas en prosa Pasión de la tierra, de Aleixandre, publicado también tardíamente (en Méjico -hay una segunda edición española), fue escrito cuando el poeta no tenía idea de la escuela de Breton, Aragon, etcétera; ni hay conexión transmitiva tampoco entre el superrealismo francés y Sobre los ángeles, de Alberti. La poesía francesa y la española recogieron, pues, independientemente, cosas que estaban en el aire. Después se produce un contacto de la poesía española con la francesa superrealista y hay ya influjo de ésta» (1952: 326).

16. Me refiero a «El amor en la poesía de Vicente Aleixandre», en donde Cano apuntaba: «Otros elementos románticos, y no de escaso relieve, cabría señalar en la poesía de Aleixandre. En primer lugar, una radical libertad de expresión artística, que es conquista del surrealismo, pero que en el autor de La destrucción o el amor obedece siempre a razones profundamente, misteriosamente poéticas. No por otra causa hay siempre en los poemas de Aleixandre una perfecta unidad interna, a pesar de la riqueza y variedad de elementos líricos que suelen componer cada uno de ellos» (1944: 86). Cano había expresado una opinión semejante en una reseña de 1935 sobre Pasión de la tierra, poemario que define como «la expresión de la fase surrealista de su sentimiento poético, acusada sobre todo en la forma, en la mecánica empleada. Pero esta influencia surrealista a la cual era difícil sustraerse, se muestra en estos poemas de Aleixandre sin que nos impida oír su voz auténtica de poeta, la que años más tarde iba a mostrarse plena de madurez en sus dos obras posteriores» -se refiere a Espadas como labios y La destrucción o el amor (1935: 15). 
sobre el surrealismo español». Emplear la expresión «surrealismo español» ya supone un avance considerable sobre los planteamientos que en este terreno habían venido dominando hasta esa fecha, aunque sea para decir que «como movimiento organizado e influyente -tal el francés- no ha existido jamás». Cano reconoce en este artículo el influjo del surrealismo en Aleixandre -sólo cita un libro, Espadas como labios-, en Lorca, en Alberti, en Cernuda, en José María Hinojosa, y en las revistas Gaceta de Arte y Litoral. Es más, informa incluso sobre el proyecto de publicar una revista que fuese el órgano del surrealismo español. Este proyecto surgió entre los responsables de Litoral durante una estancia de Dalí y Gala en Torremolinos. Otro de los valores positivos del texto de Arbor es que Cano reconoce la continuidad del surrealismo en la poesía de posguerra, en la obra del núcleo surrealista catalán: Julio Garcés, Juan Eduardo Cirlot y Manuel Segalá, aunque de estos poetas ya había hablado antes de 1950, en una encuesta titulada «La poesía actual según los poetas» que La Estafeta Literaria publicó en el extraordinario de 1946 (Navas Ocaña, 1995: 177-178).

Carlos Bousoño, cuyo libro sobre La poesía de Aleixandre se publicó en 1950, poco después del discurso de Dámaso Alonso, sostiene las mismas tesis que el crítico madrileño había venido formulando desde 1932. Según Bousoño, «la escuela superrealista espańola (...) nació con independencia de la escuela francesa de análoga tendencia, y sólo después, en marcha ya el movimiento hispano, puede hablarse de contactos entre una y otra» (1950: 225-226) ${ }^{17}$. Aleixandre, cuyo período surrealista se limita a Pasión de la tierra, recibió el influjo no del movimiento francés sino de la «tradición visionaria española» y de la lectura de Freud, Rimbaud y Joyce. Después, gracias a una «sucesiva depuración» alcanzó la «clásica limpidez de Sombra del paraíso y de los libros subsiguientes» (Ibid.: 226). Por otra parte, y siempre

17. A propósito de esta cuestión, no sólo cita a Dámaso Alonso sino también a Gerardo Diego, que por esas mismas fechas había publicado el artículo "Vicente Aleixandre» ( $A B C$, Madrid, 26 de enero de 1950), en donde negaba de nuevo el influjo francés sobre la poesía aleixandrina: «Pero podemos asegurar que entre la poesía de esos libros -se refiere a Pasión de la tierra y Espadas como labios- y la de los poetas iniciadores del "surréalisme" hay no menor distancia que entre la novela naturalista y determinista de Zola y la de los primeros libros de Emilia Pardo Bazán o Armando Palacio Valdés. Menor distancia, sin duda, puesto que estas novelas son conocedoras de la novedad parisina, y aquéllos, poemas inocentes de manifiestos y tentativas transpirenaicas». Y continúa: «Del mismo modo, la poesía en aquellos libros de Aleixandre, superados en la plenitud de los posteriores, obedece no a ninguna moda de ultrapuertos, sino a una evolución interior autónoma y necesaria, a una crisis espiritual, expresiva, y hasta patológica, a una comunicación con el espíritu del tiempo que le llega al poeta a la vez que a otros poetas de lengua española, sin sometimiento alguno a fórmulas ni a teorías que indudablemente le repugnan». 
fiel a su maestro Dámaso Alonso, Bousoño dice que, aunque en la teoría Breton hubiese hablado de "automatismo psíquico puro», "en la práctica el superrealismo puro nunca existió». Y añade: «en España, desde luego, ningún poeta en sus versos parece haber pretendido aquella extremosidad» (Ibid.: 225).

Manuel Durán, en el primer estudio monográfico sobre el tema, El superrealismo en la poesía española contemporánea (1950), desarrolla las tesis de Dámaso Alonso sobre el automatismo con una distinción muy particular entre escritura automática y poema surrealista, entre poesía surrealista y "surrealismo a secas», convencido de que la utilización de los materiales del subconsciente con un fin estético siempre implica un «esfuerzo consciente» ${ }^{18}$. Desde las teorías de Ortega sobre la deshumanización, de grandísimo impacto en la tradición crítica de este siglo, ni los poetas ni los críticos se resignan a perder el alto rango que éstas les conferían, el inmenso grado de protagonismo que les suponen, la condición de arte, de especialización, de consciencia, de técnica, etc. ¿Cómo se habrían entonces de enfrentar al movimiento surrealista, destructor del mito del poeta artífice, potenciador de aquellos ámbitos sobre los cuales el ser humano no puede ejercer un dominio consciente? De este combate de fuerzas contrarias surgen argumentaciones como la de Dámaso Alonso, o la de Durán, que son, en realidad, soluciones de compromiso, muy frecuentes en nuestra Estilística: nunca un formalismo radical, pero tampoco un contenidismo exacerbado. Por otra parte, la tesis de un surrealismo espańol sin escritura automática iba tomando cuerpo desde el momento en que Dámaso Alonso apuntó la posibilidad para el caso de Aleixandre. El ensayo de Durán resulta modélico al respecto. Después de haber negado la posibilidad de automatismo en los poemas surrealistas, de haber considerado este hecho un rasgo típico de toda la lírica surreal, nos

18. «El relato de un sueño y la escritura automática (...) nos ponen en contacto con el subconsciente del que los relata o escribe, y ello en forma auténtica y válida. El poema no. Por mucho que se parezca al texto surrealista, el poema denota un esfuerzo consciente -por mínimo que sea- de ordenación, de sustitución de unas palabras por otras, en un intento deliberado de producir un aspecto artístico. El poema surrealista utiliza los materiales que le proporciona el subconsciente para elaborarlos con vistas a un fin estético.

Basta comparar los más bellos poemas surrealistas de Paul Eluard con un texto automático cualquiera para comprender el abismo estético que separa la poesía surrealista del surrealismo como expresión a secas. El material empleado es casi el mismo: frases a veces inconexas e incoherentes, desprecio por la puntuación y la gramática, sinuosidad de la expresión que se mueve a un ritmo enigmático e imprevisible. Pero el poema surrealista, mediante un esfuerzo de selección y de sustitución análogo al de toda obra artística, se ha convertido en poesía, mientras que el texto sigue siendo amarga "prosa» -prosa, por otra parte, sumamente aburrida» (1950: 17-18). 
sorprende afirmando la peculiaridad no automática de la variante española. Entre las características del «desarrollo de las tendencias surrealistas en España», señala que "cuando consigue imponerse, raras veces lo hace en la forma pura de la escritura automática» (Ibid.: 39), con las excepciones de Picasso y José María Hinojosa, los dos únicos casos de «surrealismo ortodoxo y total» (Ibid.: 59). Si la poesía surrealista no es automática, ¿qué sentido tiene establecer un subgrupo de la corriente general en razón de ese rasgo?, ¿por qué hablar de ortodoxia y heterodoxia? En el trabajo de Durán, primera -insisto- monografía sobre esta controvertida cuestión, conviven y se entrecruzan las teorías que hasta la fecha la crítica española había ido elaborando: la de Dámaso Alonso y sus reticencias sobre el automatismo, la de Salinas y sus reticencias sobre el automatismo para el caso de Espańa, la de Dámaso y su resignada aceptación del termino surréalisme, etc.

Pues bien, ya iniciada la década de los cincuenta, José Albi y Joan Fuster, en su Antología del surrealismo español (1952), establecerán definitivamente la singularidad no automática de nuestro surrealismo. Y lo primero que intentan resolver es la aceptación definitiva como surrealistas de esos productos no automáticos. Ofrecen entonces una solución muy interesante. Creen que el automatismo fue ley ineludible sólo «en los comienzos de la escuela». Así lo prueba, la posterior distinción de Eluard entre escritura automática, relato de un sueño y poema surrealista, que recuerda mucho a la de Durán. Habría, por tanto, «dos tipos opuestos de surrealismo», que encarnarían Joan Miró (pura espontaneidad) y Salvador Dalí («aprovechamiento racional» del subconsciente), y que el mismo Breton alterna en su obra: mientras «L'Union Libre» les parece un poema automático puro, en la «Ode à Charles Fourier» Breton, «sin abdicar del automatismo, se limita a dar entrada en el poema a elementos voluntarios y discursivos, de consciencia: en una palabra, tiende un hilo -sólo un hilo- de intencionalidad para ensartar la fluencia automática» (1952: 3-4) ${ }^{19}$.

De todas formas, a lo largo de los años cincuenta el surrealismo deberá enfrentarse otra vez a un clima poco favorable, propiciado ahora por los nuevos planteamientos de la poesía social, cuyo germen se halla en la revista leonesa Espadaña. Allí se publica una conferencia de Pablo Neruda, en la cual el poeta chileno no duda en afirmar que el surrealismo, ya «fallecido y enterrado», "sólo sirvió para que de este movimiento se levantaran como

19. En la reseña que Gerardo Diego publicó sobre la antología de Albi y Fuster se advierten las mismas reticencias de Dámaso Alonso para aceptar el término «surrealismo»: «Surrealismo en español no deja de ser un galicismo, pero lo más grave y, después de todo, lo más expresivo, es que al imitar, al copiar la fonética francesa, resulta en castellano una voluntad de significación opuesta. No la sobrerrealidad, sino la sub-realidad o infrarrealidad» (1952: 4). 
dos estatuas deslumbrantes de la razón y la fe en el hombre, los dos grandes poetas de Francia: Louis Aragon y Paul Eluard» (1950: 927). Por tanto, el valor del surrealismo reside para Neruda únicamente en haber propiciado el surgimiento de dos grandes poetas que abjuraron de su militancia surrealista para tornarla en comunista. Y es que los teóricos de la poesía social, desde las nuevas preocupaciones colectivas, rechazarán lo que ellos consideran el «subjetivismo» del arte contemporáneo, adjudicándole de nuevo al surrealismo, y con él a toda la vanguardia, un perfil romántico. Por eso, Eugenio G. de Nora, en un artículo emblemático -«Machado ante el futuro de la poesía lírica» (1949) - se opondrá a todas aquellas corrientes que primen lo individual, ya sea en la versión estrictamente romántica -la expresión del yo- o en la vanguardista y pura -exacerbación de las prerrogativas del individuo, desplazadas a la obra ${ }^{20}$. Y Celaya expresará su desprecio por el surrealismo tildándolo de simple romanticismo, considerándolo una versión actualizada de la inspiración romántica ${ }^{21}$. La poesía de Vicente Aleixandre será, en consecuencia, objeto de una nueva lectura. Nora, que entre 1943 y 1945 había expresado con apasionamiento su fervor por ella, nos sorprenderá a la altura de 1950 haciéndole algunas objeciones. Ahora va a enjuiciar la trayectoria de Aleixandre de acuerdo con la mayor o menor presencia del ser humano. Como es muy escasa, concluye que se trata de una «obra de evasión y ensueño, edificación de mundos de belleza ideal, (...) para esquivar la nulidad del hombre concreto, la fealdad del gastado mundo actual». Nos hallamos, dice Nora -y obsérvese la radicalidad de la siguiente frase-, ante «la más violenta antítesis de la humanización y centralización biográfica que busca la poesía de hoy». Aleixandre, que en 1944 fue para el espadañista el «vendaval furioso" capaz de acabar con toda la tradición esteticista europea (Navas Ocaña, 1996 a: 27-32), en 1950 es un poeta puro, como lo fueron los de su generación, acaso el que más ${ }^{22}$. Si antes valoró la sinceridad, la elementalidad

20. «En efecto, la atomización y el subjetivismo artístico que queremos superar se iniciaron ya en el romanticismo. Se iniciaron precisamente con un repliegue del poeta hacia su propio yo. La disgregación después avanza del sujeto a la obra -el arte puro-, de la obra a elementos y aspectos parciales de la misma -la palabra, la imagen exterior: véase dadaísmo, creacionismo, retorno a la estrofa, etc.- y finalmente cumpliendo un ciclo, cerrando un paréntesis abierto por los románticos, vuelve a recogerse en la conciencia individual» (1949: 587).

21. "Todos los "ismos", quiéranlo o no, fueron románticos, o tan románticamente antirrománticos como el Futurismo. El Surrealismo, último de esos "ismos", con su automatismo (nuevo nombre de la inspiración), su defensa de la "belleza convulsiva", su pathos de lo monstruoso y su debilidad ante lo maravilloso, recogía de hecho, las más puras consecuencias del librelirismo romántico» (1948: 18).

22. «Y es que Aleixandre no podía ser en su generación un caso totalmente excepcional, aunque con una originalidad asombrosa en cuanto al modo, el arranque y la meta de su poesía 
y la vitalidad de la poesía de Aleixandre, ahora la acusa de "poética», de irreal, de pura, de inhumana. ¿Cómo ha podido producirse un cambio tan drástico? Pues bien, este cambio se explica a partir de la evolución teórica que ha sufrido Nora, desde el neorromanticismo a la poesía social. En efecto, un neorromántico elevaría a la más excelsa cumbre los poemas aleixandrinos, exponentes de una individualidad tan marcada, tan apasionadamente peculiar, tan distinta del monocorde orfeón garcilasista. Pero un teórico de la poesía social echaría en falta la presencia del hombre, de los problemas en los que éste se debate como ser histórico, etc. No hay que perder de vista que la suerte del surrealismo en la crítica espańola va a estar estrechamente ligada a la figura de Aleixandre. Si éste fue considerado hacia mediados de la década el paladín de la rehumanización neorromántica, el surrealismo, de forma paralela y aunque sin lograr granjearse el favor absoluto de los críticos, es considerado también un movimiento rehumanizador. En 1950, cuando la poesía social exige una humanidad más radical y Aleixandre obtiene el calificativo de poeta puro, el surrealismo reingresa en ese panorama general de deshumanización en el que el modelo garcilasista incluyó tempranamente a toda la vanguardia. Y decimos reingresa porque el neorromanticismo lo había excluído, había hecho una excepción con él, excepción que la poesía social va a eliminar.

Una crítica similar recibirá Miguel Labordeta en Espadaña. Transeúnte central será motivo de la siguiente reflexión por parte de los redactores de la revista: «¿Es posible que aún los poetas puedan permitirse el lujo de retorcerse y segregarse "acechando al brujo de los manómetros", como si en el mundo no existieran temas de más alto empeño que servir?...» (1950: 941). Los planteamientos de corte social que Celaya, Crémer y Nora vienen sosteniendo desde 1949 hacen aquí su aparición. La nueva orientación social trae consigo una reformulación, una redefinición de las vanguardias. El surrealismo no es ya una excepción, pierde las prerrogativas que había disfrutado con el modelo neorromántico. La lectura en clave deshumanizadora le atañe también a él. Reaparece, además, una vieja incompatibilidad entre vanguardia y compromiso, reforzada por el ingreso del surrealismo en esa larga lista de «ismos» intrascendentes y deshumanizados. En este ingreso debió de influir poderosamente una variante de esa vieja incompatibilidad: las tormentosas relaciones del surrealismo con el partido comunista francés.

son, como -inicialmente- en todos sus compañeros -y con una decisión e insistencia mayores que en ninguno de ellos-, una creación estética, la aspiración a una obra pura de arte; no, como intentan los poetas de hoy, la expresión de una personalidad y la consecuencia directa de ella». 
Estas tormentosas relaciones suscitaron también el interés de algunos críticos que, desde posiciones ideológicas completamente opuestas, pretendían advertir sobre la imposibilidad de conjugar poesía y política, y expresar en última instancia su disconformidad con los nuevos afanes colectivistas de la poesía social. Así lo hizo Juan Eduardo Cirlot en su Diccionario de los ismos (1949) ${ }^{23}$, anticipo de la postura que mantendría un año más tarde en la célebre polémica sobre la poesía popular con el artículo titulado «iAbajo la máquina de trovar! La condición actual de nuestros poetas» (Navas Ocaña, 1997a: 100-101). En Ínsula Rolland de Reneville publicó un análisis de la «Situación actual del surrealismo» (1947), que también planteaba la discordia, la imposible conciliación, entre el idealismo surrealista y el materialismo comunista ${ }^{24}$. Y Ramón Gómez de la Serna se ocupó del tema en su «Ultimatum del surrealismo» (1956), aunque con mayor esquematismo. De la Serna no observa en la filosofía surrealista una contradicción idealismo/materialismo con las dimensiones apuntadas por Reneville, sino simplemente una lucha entre facciones -trostkistas y stalinistas- dentro del marxismo ${ }^{25}$. Esta problemática aparece además en el monográfico que Cobalto, revista barcelonesa de arte, dedicó en 1948 al movimiento francés. No se ha destacado quizás lo insólito de esta dedicatoria en un período, los años cuarenta, poco propicio, por no decir francamente hostil. El número, se abre con un trabajo de Rafael Santos Torroella titulado "Genio y figura del surrealismo. Anécdota y balance de una subversión». A

23. «Para el neosurrealismo, tal como lo concebimos, el intento de una revolución política del orden comunista es sencillamente algo tan espantosamente triste y estéril como el intento de cometer un crimen con pistola de juguete. No se trata de elevar el nivel de una clase social ni de hacer su existencia más bella por la poesía; se trata de levantar el nivel de la potencia creadora del espíritu en su acción en la tierra, para que el hombre pueda sentirse superior a sí mismo» (1949: 255-256).

24. «De hecho, ninguna concomitancia era posible en una teoría que concebía la revolución como el advenimiento de una era de libertades que debieran destruir para siempre todas las ataduras, los mitos religiosos y políticos, asegurando el triunfo del individuo por fin liberado de los imperativos sociales, y una doctrina que sólo atacaba los mitos de la sociedad burguesa por ser el producto de una economía fundada sobre el capitalismo liberal, pero que no renunciaba a resucitar la mayor parte de esos imperativos en el marco de una sociedad dictatorial apoyada en el capitalismo estatal».

25. «Todo iba bien hasta que el extranjerismo político se mezcla en el asunto y André Breton se muestra dispuesto a preparar el "desvío definitivo de las fuerzas intelectuales en provecho de la fatalidad revolucionaria". Picasso, que es "la revolución permanente" de la pintura, redobla su adhesión a Breton, pero después de la sindicación llega la persecución de Trostky, y, como son trostkistas, quedan a un lado, y eso hace que el Surrealismo se disgregue y se quede Breton solo con unos cuantos incondicionales» (1956: 36). 
pesar de estar muy bien documentado, de incluir una interesante historia del surrealismo y una descripción minuciosa de las actividades y procedimientos surrealistas, Torroella entona un canto de defunción: «la hora del surrealismo (...) ha tocado a su fin» (1948: 5). De hecho, habla incluso de una especie de «industrialización", provocada por una difusión tan amplia que ya nadie lo considera "peligroso», "ya nadie teme aquella virulencia que le caracterizaba» (Ibid.: 6). Hoy, añade, «se habla de él como pura veleidad de un puñado de pintores y de poetas» (Ibid.: 10). Además, se muestra tajante en lo que concierne a la participación española: los pintores españoles que mantuvieron alguna relación con el surrelismo (Picasso, Dalí, etc.) en realidad son artistas desarraigados, sin raíces en nuestro país ${ }^{26}$. Aparece aquí el tópico de la vanguardia como algo importado. Torroella destaca también el antipatriotismo surrealista ${ }^{27}$ y critica incluso su incapacidad para someterse a una disciplina de partido (así da cuenta del tormentoso episodio con el comunismo $)^{28}$. Completan este número monográfico dos artículos en francés: uno de Bernard Dorival sobre la pintura surrealista y otro de J. L. V. Brans titulado «Surréalisme antique et moderne». Brans se aplica en la búsqueda de antecedentes -el arte egipcio, el Bosco, etc. Una tarea similar emprende Carlos Cid con el trabajo «Arte religioso. ¿Surrealismo en los capiteles románicos?». Por último, el doctor Juan Ramón de Otaola da una explicación psiquiátrica del surrealismo como «erupción de todos los apetitos y sentimientos reprimidos y negados por las principales ideas de la cultura vigente». Esto posee una «significación psicológica enteramente negativa», que provoca la frecuente afloración de «neurosis, toxicomanías y suicidios» (1948: 52). En este número de Cobalto se dan cita muchos de los prejuicios que jugaban entonces un papel capital en el enjuiciamiento del

26. «(...) aunque es lo cierto que españolas son algunas de las firmas más relevantes con que ha contado el surrealismo, no lo es menos el que jamás arraigaron en el ámbito artístico de la Península. Pero del mismo modo que el universal renombre de un Miró o de un Dalí no despertaban entre nosotros interés ni preocupación excesivos, tampoco debían apresurarnos, aquietadas ya las turbulencias iniciales, hacia una comprensión y reconocimiento mayores, tanto para las obras de los surrealistas catalanes como para las de sus colegas del grupo surrealista parisién. En resumidas cuentas, que tanto unos como otros no han sido tomados en Espańa, ni para bien ni para mal, demasiado en serio.»

27. «Así, cuando para todo francés la vencida Alemania era el enemigo secular que había que reducir de una vez por todas a la impotencia, ellos son los únicos que se atreven a lanzar a todo pulmón el grito de ;Viva Alemania!) (Ibid.: 11).

28. «Los surrealistas, aun cuando en repetidas ocasiones coquetearon con los partidos marxistas, hasta llegar incluso a conversaciones para emprender una actividad conjunta, lo cierto es que no pudieron acomodarse en ningún momento a esa disciplina de partido que constituye la mejor de las garantías para la efectividad de un movimiento auténticamente revolucionario» (Ibid.: 11). 
surrealismo: el fin de la vanguardia, su carácter importado, nacionalismo exacerbado, búsqueda de predecesores en los ámbitos más insospechados para así aminorar el impacto de la subversión surrealista ${ }^{29}$, comportamientos políticos y sociales anticonvencionales, etc. Por lo demás, el binomio surrealismo-comunismo fue esgrimido en la posguerra contra el movimiento postista en toda una serie de críticas que si por algo sobresalen es por su virulencia ${ }^{30}$.

Pues bien, no resultaría nada fácil hacer frente a toda esta suerte de prejuicios, que tan hondamente parecían haber calado en la crítica española. Por lo pronto, ya en los años sesenta los trabajos de Vittorio Bodini-Los poetas surrealistas españoles (1963) - y Paul Ilie -Los surrealistas españoles (1968)propician una puesta al día de la problemática del surrealismo en España que, si en cierta forma continúa la línea establecida por Dámaso Alonso, Durán o Albi y Fuster (no en vano Ilie viene a refrendar la existencia de un surrealismo español claramente diferenciado del francés entre otras razones por la problemática del automatismo), abre también otras posibilidades que van a cuajar en la década siguiente. Por ejemplo, a propósito de la escritura automática, Bodini cita una carta de Breton a Roland de Reneville en la que se reconoce cierta vigilancia racional aún en los textos más pretendidamente automáticos ${ }^{31}$. Bodini recoge este testimonio para probar, como ya hiciera Dámaso Alonso en 1932, que el automatismo puro no existe ${ }^{32}$. Pero, aún así, apunta un dato fundamental que muy pronto será utilizado por otros investigadores para negar la existencia de un surrealismo español. De todas formas, en estas fechas la crítica española, al hacerse eco de los trabajos de estos hispanistas extranjeros, insiste en lo que ya eran tópicos. Por ejemplo, Alberto

29. Hay unas palabras de Eugenio D'Ors en «Superrealismo y arte abstracto» (1949) que me parecen muy apropiadas al respecto: «Pero el arte superrealista es tan antiguo como el mirar o el oír. ¿ No tienen derecho a entrar en la cofradía de la escuela, desde el niño, a quien asusta el coco y la bobalicona, que, de noche, ve "un hombre" en el gabán colgado de una percha, hasta la heroína que oyó voces, o el Santo que recibió impresión de llagas?».

30. Valga como muestra la siguiente, publicada en 1946 en El Español bajo el seudónimo de «Eolo»: «Se os ha tachado por algunos de pseudo francófilos, comunistoides, rusófilos y masonizantes. Ignoramos lo que haya de verdad. Pero os retamos a una defensa de la Patria y os exigimos una retracción. Comenzar diciendo quiénes sois, cómo os adjetiváis y lo que pretendéis, pero jamás intentéis algo en nombre de España».

31. «Nunca hemos pretendido dar un texto surrealista cualquiera como ejemplo perfecto de automatismo verbal. Incluso en el mejor texto "no controlado" se advierten, hemos de reconocerlo, ciertas resistencias. En general, un mínimo de control subsiste, en el sentido de equilibrio poético» (apud Bodini, 1963: 31).

32. "Pero el automatismo puro no es posible, tanto menos en poesía, donde las propias exigencias del poiein, del hacer poético, imponen un mínimo de organización semántica de los mensajes transmitidos por el inconsciente» (1963: 31). 
Adell, al reseñar el libro de Ilie en Ínsula, no parece muy conforme, aunque tiene algunas dudas, con la adscripción de los poetas españoles al surrealismo por la ausencia de escritura automática y retoma la argumentación de Dámaso Alonso sobre «eso que está en el aire». En cuanto a Joaquín Marco, la serie "Muerte o resurrección del surrealismo español» (1973) abunda más en las causas que impidieron la conformación de un grupo surrealista organizado en nuestro país (cuestión que Bodini también había tratado por extenso). Marco habla del carácter importado que la vanguardia tiene en España, de su falta de radicalismo, y concluye: «Los poetas hacian surrealismo, no eran surrealistas», «afectó principalmente a las formas de expresión» (1973: 10). Con esta conclusión parecen por fin liquidadas toda una serie de inquietudes de carácter político, moral e incluso estético que habían pululado sobre la crítica española y que habían dificultado la aceptación del surrealismo en el 27 y en la poesía de posguerra. Dar un paso más, negar la existencia de un surrealismo hispánico y otorgar a los poetas españoles el calificativo de surrealistas sin más sería sólo cuestión de tiempo. Como también sería cuestión de tiempo el hecho de que se comenzara a estudiar la pervivencia del surrealismo en la poesía de posguerra, posibilidad esta última también apuntada y desarrollada ampliamente por Joaquín Marco en el segundo artículo de la serie, con interesantes puntos de vista sobre Cirlot, Labordeta, el postismo, los novísimos, la poesía experimental, etc. Por supuesto, no hay que olvidar que todo este interés crítico de los años sesenta y setenta en torno al surrealismo viene propiciado desde el ámbito de la creación literaria por el surgimiento de las llamadas neovanguardias (experimentalismo, visualismo, concretismo, etc.) y por la promoción de los poetas novísimos, que en su rechazo de la poesía social volverá los ojos a grupos como el postista o a poetas como Cirlot y Labordeta (Navas Ocańa, 1997b: 18-19).

La publicación además en estas fechas de Documents of the Spanish Vanguard (1969) de Paul Ilie y Surrealism and Spain (1972) de C. B. Morris pondrá al descubierto la abundante información que tuvieron los poetas del 27 sobre las actividades del grupo francés y dejará en entredicho las declaraciones de algunos de ellos sobre su desconocimiento de las tesis surrealistas. Y la aparición en 1975 de Facción surrealista española de Tenerife de Domingo Pérez Minik demostraría la existencia de un grupo surrealista organizado en España, aspecto que mereció también la atención de C. Brian Morris (El Manifiesto surrealista escrito en Tenerife,1983). Este hecho propició la posibilidad de realizar estudios sobre núcleos regionales surrealistas en nuestro país, posibilidad esbozada por Ramón Buckley en el número monográfico con el que Ínsula celebró el cincuentenario del surrealismo 
en $1974^{33}$. A tenor de la información aportada por los trabajos de Ilie, Morris y Pablo Corbalán, Buckley pretende dar una «visión regionalista del surrealismo" (1974: 3), distinguiendo un «surrealismo ortodoxo», que sería el del grupo catalán (Dalí, Miró y Foix), un "surrealismo vanguardista», el del grupo madrileño (en el que incluye a Gerardo Diego, Domenchina, Francisco Ayala, Gómez de la Serna, José Díaz Fernández, Benjamín Jarnés, Max Aub, Mauricio Bacarisse y Antonio Espina, y que se caracteriza por aglutinar tendencias muy diversas: futurismo, ultraísmo, teorías de Ortega, etc.), un "surrealismo telúrico», propio de los poetas andaluces (Aleixandre, Cernuda, Lorca, Prados y Altolaguirre), y un «surrealismo expresionista», el del grupo canario de Gaceta de Arte, más directamente comprometido desde el punto de vista político-social. Esta línea de trabajo tendrá cierta continuidad en los ańos siguientes con estudios como el de M. Pérez Lizano sobre el Surrealismo aragonés 1929-1979 (1980) o el volumen editado por Andrés Sánchez Robayna dedicado a Canarias: las vanguardias históricas (1992). Por lo demás, estas diferencias regionales ya apuntaban tímidamente, como el mismo Buckley indica, en la antología Poesía surrealista en España de Pablo Corbalán, editada en 1974. Pero esta antología destaca sobre todo por distanciarse desde el título mismo de quienes venían sosteniendo la existencia de un surrealismo hispánico y por aducir, en relación a la escritura automática, un fragmento de una conferencia de Breton en Praga («Posición política del arte de nuestros días», 1935), en donde se afirmaba que «El automatismo psíquico - ¿es verdaderamente indispensable volver sobre ello?no ha constituido nunca para el surrealismo un fin en sí mismo, y pretender lo contrario es cometer un acto de mala fe» (apud Corbalán, 1974: 25). Carlos Feal formulará esta idea de forma mucho más clara en 1979: «En mi opinión, los escritores y críticos citados que invocan la desobediencia de la regla básica del "automatismo psíquico" para negar que exista un surrealismo español, o al menos para distinguirlo del francés, cometen un error. Error procedente de una lectura parcial, y por tanto equivocada, de Breton» (1979: 272). Y para apoyar esta idea, Feal recoge la puntualización que sobre el tema hizo Breton ya en el primer manifiesto ${ }^{34}$. Pues bien, si el automatismo no fue

33. Otras revistas celebraron también este cincuentenario con sendos números monográficos: Informaciones de las Artes y las Letras, Destino, El Urogallo. Desde entonces Ínsula ha vuelto a publicar varios monográficos sobre el tema $(1989,1996)$ y habría que recordar también el de El Viejo Topo en 1978, el de Litoral en 1987 y el de Turia en 1993.

34. «Si las profundidades de nuestro espíritu ocultan extrañas fuerzas capaces de aumentar aquellas que se advierten en la superficie, o de luchar victoriosamente contra ellas, es de mayor interés captar estas fuerzas, captarlas ante todo para, a continuación, someterlas al dominio de nuestra razón, si es que resulta procedente» (apud Feal, 1979: 272). 
una exigencia inexcusable en las tesis bretonianas, la cuestión de la escritura automática no es entonces lo suficientemente relevante como para negar la adscripción de los poetas españoles al surrealismo o para hablar de una modalidad surrealista española discrepante de la francesa. Esta posición la comparte otro investigador, Jesús García Sánchez, que en la "Introducción» a Surrealismo. El ojo soluble, monográfico sobre el tema de la revista Litoral (1987), aboga por una perspectiva amplia, internacional, sin localismos, y, respecto a la escritura automática, puntualiza: «Que los mecanismos de creación fueran más o menos "ortodoxos" no desvirtuaba el resultado final de la obra. Eso lo sabía Breton (y lo reconoció en más de una ocasión), y lo sabían nuestros escritores, pues su producción era finalmente equiparable al mejor surrealismo literario del momento» (Ibid.: 18). García Sánchez es autor también de La recepción del surrealismo en España (1924-1931) (1984), un estudio que pondrá de nuevo en evidencia la cantidad de información que se tuvo en nuestro país sobre el surrealismo entre 1924 y 1931, y que completará ańos después con una interesante Bibliografía y Critica del Surrealismo y la generación del 27 (1989). En la década de los ochenta se publica también El surrealismo español de Francisco Aranda (1981), surrealista confeso él mismo. Sin embargo, este hecho, que podría haber sido muy positivo para la definitiva «normalización» del tema en nuestro país, para que la problemática del surrealismo se tratase sin prejuicios, queda oscurecido por el fárrago de datos y en algunos casos de inexactitudes que críticos como Antonio Martínez Sarrión (1981), Eduardo Haro Ibars (1981) y Yolanda Novo (1982) se apresuraron a señalar en el libro de Aranda.

Por otra parte, el debate sobre el surrealismo español se planteará también a propósito del movimiento postista, que no había tenido reparos en declarar sus deudas con el movimiento francés, aunque se había distanciado de él al rechazar el automatismo psíquico puro para, mediante la técnica, convertir en productos estéticos los materiales aportados por el subconsciente. La cuestión está apuntada por Ory en «Surrealismo ibero y apertura de polémica» (1952) y en "Surrealismo en Espańa» (1972). Si por un lado se considera que el postismo puede ser parte de esa modalidad espańola, en virtud del empeño, compartido con los poetas del 27, por intervenir racionalmente en la materia emanada del subconsciente, por otro lado, y, al margen de la siempre controvertida cuestión del surrealismo español, se opta por singularizar la aventura postista respecto al movimiento francés. Rafael de Cózar recoge estas dos opciones ${ }^{35}$ y Jaume Pont abunda en ellas poniendo un énfasis especial en el

35 «A un nivel estricto, nada permite, a pesar de las coincidencias, apodar la "Nueva Estética" (el Postismo) como Surrealismo hispánico, ya que ésta superaba los márgenes 
carácter «revisionista» del postismo, en sus vínculos con otros movimientos de vanguardia y no sólo con el surrealismo (1987: 102-103).

Lo cierto es que desde la década de los setenta se han sucedido los estudios sobre el surrealismo en los poetas del 27. La poesía de Vicente Aleixandre será otra vez una de las primeras en recibir la atención de una crítica ya mucho más favorable al movimiento francés. Además, el propio Aleixandre contribuye a esta nueva situación publicando en 1971 una antología de Poesía superrealista. Entre la infinidad de trabajos que se editarán desde entonces sobre el surrealismo aleixandrino, baste citar los de Hernán Galilea (1971), Yolanda Novo (1980) o Gabriel Morelli (1989 y 1996). Y otro tanto ocurrirá con sus compañeros de generación. Recuérdense los artículos de Derek Harris sobre Cernuda (1962 y 1982), la monografía de Capote Nevot (1976), los estudios de Julio Neira sobre Hinojosa (1982), los de Patricio Hernández sobre Emilio Prados (1987, 1996), etc. Si añadimos algunos interesantes análisis sobre la recepción crítica del surrealismo (Personneaux Conesa, 1983 y 1986; Neira, 1983; Arce Oliva, 1986) y sobre la presencia del surrealismo en poetas de posguerra como Labordeta, Ory, Cirlot (Maícas, 1993 y Medina, 1998), etc., habremos recorrido un largo camino, que nos ha traído hasta aquí para poder hablar del surrealismo con todas las consecuencias o, mejor, con ninguna.

\section{REFERENCIAS BIBLIOGRÁFICAS}

Adell Alberto, «Inquisición del surrealismo español», Ínsula, Madrid, no 284-285, 1970, pp. 20-21.

Alberti Rafael, La poesía popular en la lírica española contemporánea, Jena \& Leipzig, Wilhelm Gronau, 1933.

Albi José y Fuster Joan, Antología del surrealismo español, Verbo, Alicante, no 23-2425, febrero de 1952.

Aleixandre Vicente, Pasión de la tierra, México, Ed. Fábula, 1935; Madrid, Adonais, 1946. Ed. de Gabrielle Morelli, Madrid, Cátedra, 1987.

- Sombra del paraíso, Madrid, Adán, 1944.

exclusivos de la escuela francesa, la reproducía sintetizada junto a la síntesis de otras tendencias (...). Es así tendencia sintética, decimos, que va detrás y recoge aspectos de los diversos ismos. (...) A otro nivel, si partimos de una concepción universalista del arte (...) nada nos impide calificar al Postismo como Surrealismo español incluido en la segunda etapa de su extensión europea, ya que el Surrealismo, como el Romanticismo, escapa a los márgenes exclusivos de un país o de una época, y es concepto del arte universal, titulación genérica de las diversas particularizaciones nacionales» (1978: 63-64). 
- Poesía superrealista, Barcelona, Barral, 1971.

Alonso Dámaso, "Espadas como labios», Revista de Occidente, Madrid, Tomo XXXVIII, no CXIV, octubre de 1932, pp. 323-333.

- "La destrucción o el amon", Revista de Occidente, Madrid, Tomo XLVIII, no CXLIV, abril de 1935, pp. 331-340.

- «Alondra de Gerardo Diego (Poesía de Verdad»), Escorial, Madrid, Tomo XI, Cuaderno 30, abril de 1943, pp. 119-141.

- «Visión paradisíaca en la poesía de Aleixandre», El Español, Madrid, no 93, 5 de agosto de 1944, p. 7.

- «Poesía arraigada», Cuadernos Hispanoamericanos, Madrid, no 9, mayo-junio de 1949.

- Poetas españoles contemporáneos, Madrid, Gredos, 1952.

Aranda Francisco, El surrealismo español, Barcelona, Lumen, 1981.

Aranguren José Luis, «Poesía y existencia», Insula, Madrid, no 42, 15 de junio de 1949, pp. 1-3.

Arce Oliva E., «Surrealismo español y surrealismo en España. Reflexiones acerca de algunas discrepancias terminológicas», Studium, Colegio Universitario de Teruel, 2, 1986, pp. 57-71.

Benítez Clarós Rafael, "Vicente Aleixandre y Sombra del paraíso», Cuadernos de Literatura Contemporánea, Madrid, Tomo III, 1944, pp. 261-273.

Bodini Vittorio, Poetas surrealistas españoles, Barcelona, Tusquets, 1971, 1a edición 1963.

Bousoño Carlos, La poesía de Vicente Aleixandre, Madrid, Ínsula, 1950.

Brans J. L. V., «Surréalisme antique et moderne», Cobalto, II, 1948, pp. 17-21.

Breton André, Manifiestos del surrealismo, Madrid, Guadarrama, 1969.

Buckley Ramón, «¿Surrealismo en Espańa?», Ínsula, Madrid, no 337, diciembre de 1974, pp. 3 y 5.

Cano José Luis, «Pasión de la tierra. Vicente Aleixandre», Sur, Málaga, diciembre de 1935 , p. 15.

- «Un centenario. Lautréamont, padre del surrealismo», Insula, Madrid, no 5, 15 de mayo de 1946, p. 5.

- «Noticia retrospectiva sobre el surrealismo español», Arbor, Tomo XVI, no 54, junio de 1950, pp. 334-335.

Cansinos-Asséns Rafael, "La nueva lírica», Cosmópolis, no 5, 1919; en Paul Ilie, Documents of the Spanish Vanguard, Chapel Hill, University of North Carolina Press, 1969, pp. 171-178.

Capote Nevot J. M., El surrealismo en la poesía de Luis Cernuda, Sevilla, Universidad de Sevilla, 1976.

Celaya Gabriel, «Veinte años de poesía (1927-1947), Egan, no 2, 1948; en Poesía y Verdad. Papeles para un proceso, Barcelona, Planeta, 1979, pp. 16-22. 
Cid Carlos, «Arte religioso. ¿Surrealismo en los capiteles románicos?», Cobalto, Barcelona, II, 1948, pp. 59-62.

Cirlot Juan Eduardo, Diccionario de los ismos, Barcelona, Argos, 1949.

- «Abajo la máquina de trovar! Condición actual de nuestra poesía», Correo Literario, Madrid, no 15, 15 de diciembre de 1950, pp. 1 y 8.

Corbalán Pablo, Poesía surrealista en España. Antología, Reportaje y Notas, Madrid, Ediciones del Centro, 1974.

Cózar Rafael de, «Introducción», en Carlos Edmundo de Ory, Metanoia, Madrid, Cátedra, 1978, pp. 17-94.

Destino, «Cincuenta años de surrealismo», Barcelona, no 1929, 21 de septiembre de 1974.

Díaz Fernández José, El nuevo romanticismo, Madrid, Zeus, 1930,reedición de José Manuel López de Abiada, Madrid, José Esteban Editor, 1985.

Diego Gerardo, "Pasión de la tierra», Corcel, Valencia, no 5-6, 1944, pp. 181-182.

- «La última poesía española», Arbor, Madrid, VIII, no 22, julio-agosto de 1947, pp. 415-422.

- «Vicente Aleixandre», $A B C$, Madrid, 26 de enero de 1950.

- «Antología del Surrealismo Espańol», Correo Literario, Madrid, no 55, 1 de septiembre de 1952, p. 4.

Díez Canedo Enrique, "Llega un antepasado», Revista de Occidente, Madrid, 24, junio de 1925, pp. 405-408.

Doreste Ventura, «La unidad poética de Aleixandre», Ínsula, Madrid, no 50, «Homenaje a Aleixandre», 15 de febrero de 1950, p. 6.

Dorival Bernard, «La peinture surréaliste», Cobalto, Barcelona, II, 1948, pp. 2831.

Durán Gili Manuel, El superrealismo en la poesía española contemporánea, México, UNAM, 1950.

Earle P. G. y Gullón Germán (eds.), Surrealismo / Surrealismos. Latinoamérica y España, University of Pennsylvania, Departament of Romance Languages, 1977.

Feal Carlos, "Un caballo de batalla: el surrealismo español», Bulletin Hispanique, Université de Bordeaux, T. LXXXI, no 3-4, julio-diciembre de 1979, pp. 265279.

Gaceta Literaria, La, "Una encuesta sensacional. ¿Qué es la vanguardia?», no 83, 1 de junio de 1930 , pp. 1-3; no 84, 15 de junio de 1930, pp. 3-4; no 85 , 1 de julio de 1930, pp. 3-5; no 86, 15 de julio de 1930, pp. 3-4 y 15; no 87, 1 de agosto de 1930, p. 3; no 94, 15 de noviembre de 1930, p. 3.

Galilea Hernán, La poesía superrealista de Vicente Aleixandre, Santiago de Chile, El Espejo de papel, 1971.

García de la Concha Víctor (ed.), El surrealismo, Madrid, Taurus, 1982. 
García Gallego Jesús, La recepción del surrealismo en España (1924-1931), Granada, Ubago, 1984.

- «Introducción» a Surrealismo. El ojo soluble, Litoral, n¹74-75-76, extra. 1987, pp. 11-23.

- Bibliografía y Critica del Surrealismo y la Generación del Veintisiete, Málaga, Centro Cultural de la Generación del 27, 1989.

García Nieto José, «Algo más sobre nuestra poesía», Juventud, n 31, 19 de noviembre de 1942 , p. 2.

Gasch, Sebastián, "Del cubismo al superrealismo», La Gaceta Literaria, Madrid, no 20,15 de octubre de 1927 , p. 5.

Geist Anthony Leo, La poética de la generación del 27 y las revistas literarias: de la vanguardia al compromiso (1918-1936), Barcelona, Labor, 1980.

Gil Ildefonso Manuel, "Vanguardia y complemento de Sombra del paraiso en el último libro de V. Aleixandre», Cuadernos Hispanoamericanos, Madrid, no 15 , mayo-junio de 1950, pp. 587-590.

Giménez Caballero Ernesto, "El escándalo de L’Age d’Or en París. Palabras con Salvador Dalí», La Gaceta Literaria, Madrid, no 96, 1930, p. 3.

- «Fama póstuma. Ante el traslado de los restos de Pablo Picasso», La Gaceta Literaria, Madrid, no 100, 1931, p.1.

- «Más orígenes literarios de los sucesos actuales y subversivos de España, relatados sin ańadir un solo punto a la cosa, y dando relativa importancia a la mujer visible de Salvador Dalí, y dedicando estas líneas a Don Dámaso Alonso, su autor, Ernesto Giménez Caballero», La Gaceta Literaria, Madrid, no 106, 1931, p. 131.

- "Valor social del superrealismo», La Gaceta Literaria, Madrid, no 115, 1931, p. 8 .

- (1931d), «El comunismo espańol y Mme Eluard». La Gaceta Literaria, Madrid, no 117 , p. 6.

Gómez de la Serna Ramón, «Ultimatum del surrealismo», Clavileño, Madrid, no 39, mayo-junio de 1956, pp. 32-39.

González de Lama Antonio, «Sombra del Paraíso», Espadaña, León, no 3, 1944.

- «La poesía de Gerardo Diego», Espadaña, León, no 5, 1944.

- «Poesía y Vida», Espadaña, León, no 20, 1946.

- «Pasión de la tierra», Espadaña, León, no 25, 1947.

Guillén Jorge, «El estímulo superrealista», en Homenaje universitario a Dámaso Alonso, Madrid, Gredos, 1970, pp. 203-206.

Gullón Ricardo, «Los poetas de Adonais», Proel, Santander, II Época, no 3, otoño de 1946, pp. 127-138.

Haro Ibars Eduardo, «El surrealismo en España. Un movimiento que nunca existió», Tiempo de Historia, Madrid, no 83, octubre de 1981, pp. 114-127. 
Harris Derek, «Ejemplo de fidelidad poética: el superrealismo de Luis Cernuda», La caña gris, Valencia, no 6, 7 y 8, "Homenaje a Luis Cernuda», otoño de 1962, pp. 102-108.

- «Spanish surrealism: the case of Vicente Aleixandre and Rafael Alberti», Forum for Modern Language Studies, XVIII, 2, 1982, pp. 159-171.

Hernández Patricio, "La ética surrealista de Emilio Prados», Surrealismo. El ojo soluble, Litoral, Málaga, no 174-175-176, 1987, pp. 120-132.

- «El cuerpo desdoblado en la prosa surrealista de Emilio Prados», Ínsula, Madrid, no 592, «Imagen en libertad. Vanguardia y surrealismo en Espańa», abril de 1996, pp. 3-6.

Ilie Paul, Los surrealistas españoles, Madrid, Taurus, 1982, 1a edición 1968.

- Documents of the Spanish Vanguard, The University of North Carolina Press, 1969.

Informaciones de las Artes y las Letras, "Surrealismo, medio siglo después», Madrid, no 3, 17 de octubre de 1974.

Ínsula, Madrid, no 515, «Surrealismo Español. Domingo Pérez Minik (1905-1989)», noviembre de 1989.

Ínsula, Madrid, no 592, «Imagen en libertad. Surrealismo y vanguardia en España», abril de 1996.

Jarnés Benjamín, «Ph. Soupault: En Jouel», Revista de Occidente, Madrid, no 36, junio de 1926, pp. 388-390.

Lira Oswaldo P., «La esencia de la poesía», Escorial, Madrid, Tomo XIV, no 43, mayo de 1944, pp. 407-443.

Luis Leopoldo de, «Actualidad de Ámbito. El primer libro de Aleixandre», Ínsula, Madrid, no 52, 15 de abril de 1950, p. 2.

Maícas R. C. «El surrealismo en la posguerra española», Turia, Teruel, no 24-25, «Dossier Surrealismo», 1993, pp. 151-155.

Mainer José Carlos, «Prólogo» a Guillermo Díaz Plaja, Vanguardismo y protesta en la España de hace medio siglo, Barcelona, Los Libros de la Frontera, 1975.

Marco Joaquín, «Muerte o resurrección del surrealismo español», Insula, Madrid, no 316, marzo de 1973, pp. 1 y 20, y no 317, abril de 1973, pp. 3 y 14.

Martínez Sarrión Antonio, «Un equívoco paseo por el surrealismo español», El País/ Libros, Madrid, 19 de julio de 1981, p. 7.

Medina R., Surrealismo en la poesía española de posguerra, Madrid, Visor, 1998.

Moreau Arrabal Luce, «Breve retrospectiva del surrealismo español», Margen, París, no $11,1966$.

Morelli Gabriel, «La escritura surrealista de Vicente Aleixandre», Insula, Madrid, no 515, noviembre de 1989, pp. 11-14. 


\section{LA CRÍTICA AL SURREALISMO EN ESPAÑA}

- «La escritura surrealista de Vicente Aleixandre: Nuevos datos y algunas reflexiones», Ínsula, Madrid, no 592, "Imagen en libertad. Vanguardia y surrealismo en España», abril de 1996, pp. 20-22.

Morris C. B., Surrealism and Spain, Cambridge University Press, 1972.

- El manifiesto surrealista escrito en Tenerife, Instituto de Estudios Canarios, Universidad de La Laguna, 1983.

Navas Ocaña Isabel, Vanguardias y critica literaria en los años cuarenta. El grupo de Escorial y la "Juventud Creadora", Almería, Servicio de Publicaciones de la Universidad de Almería, 1995.

- La "Quinta del 42» y las vanguardias. Las revistas Corcel y Proel, Granada, Servicio de Publicaciones de la Universidad de Granada, 1996.

- «Clasicismo y romanticismo: dos conceptos a debate en la teoría literaria española (1925-1950), VI Simposio Internacional de la Asociación Andaluza de Semiótica, Sevilla, 28 al 31 de octubre de 1996; en Manuel Ángel Vázquez Medel y Ángel Acosta (eds.), La semiótica actual. Aportaciones al VI Simposio Internacional de la Asociación Andaluza de Semiótica, Sevilla, Alfar, 2001, pp. 263-282.

- «Tradición y Vanguardia: un mito de posguerra para estudiar el 27», VII Congreso de la Asociación Espańola de Semiótica, Zaragoza, del 4 al 9 de noviembre de 1996, En Túa Blesa (ed.), Actas del VII Congreso Internacional de la Asociación Española de Semiótica. Mitos, Zaragoza, Universidad de Zaragoza, 1998, vol. III, pp. 248-259.

- Espadaña y las vanguardias, Almería, Servicio de Publicaciones de la Universidad de Almería, 1997.

- El movimiento postista. Teoría y Crítica, Almería, Grupo de Investigación «Teoría de la Literatura y Literatura Comparada» de la Universidad de Almería, 1997.

- El postismo, Cuenca, El Toro de Barro, 2000.

Neira Julio, (1982), "El surrealismo en José María Hinojosa (Esbozo)», en Víctor García de la Concha (ed.), El surrealismo, Madrid, Taurus, 1982, pp. 271-285.

- «Notas sobre la introducción del surrealismo en España», Boletín de la Real Academia Española, Madrid, Tomo LXIII, Cuaderno CCXXVIII, enero-abril de 1983, pp. 117-141.

Neruda Pablo, «Textos no clásicos. Una conferencia de Pablo Neruda», Espadaña, León, no 44, 1950.

Nora, Eugenio G. De, «Hacia una revisión de libros capitales. La destrucción o el amor, de Vicente Aleixandre», Cisneros, Madrid, no 6, 1943, pp. 97-102.

- «Aleixandre, renovador», Corcel, Valencia, no 5-6, «Homenaje a Vicente Aleixandre», 1944, pp. 95-96.

- «Machado ante el futuro de la poesía lírica», Cuadernos Hispanoamericanos, Madrid, no 11-12, "Homenaje a Antonio Machado», septiembre-diciembre de 1949 , pp. 583-592. 
- «Mundo a solas», Correo Literario, Madrid, no 1, 1 de junio de 1950, p. 1.

Novo Villaverde Yolanda, Vicente Aleixandre, poeta surrealista, Universidad de Santiago de Compostela, 1980.

- «Francisco Aranda, El surrealismo español», ALEC, no 7, 1982, pp. 149-153.

Onís Carlos M. de, El surrealismo y cuatro poetas de la generación del 27, Madrid, Porrúa Turanzas, 1974.

Ortega y Gasset José, La deshumanización del arte, Madrid, Revista de Occidente, 1925; La deshumanización del arte y otros ensayos de estética, Madrid, Revista de Occidente, 1976.

Ory Carlos Edmundo de, «Surrealismo ibero y apertura de polémica», Correo Literario, Madrid, no 50, 15 de junio de 1952, p. 5.

- «¿Surrealismo en España?», Cuadernos Hispanoamericanos, Madrid, no 261, marzo de 1972.

Pérez Lizano Manuel, Surrealismo aragonés 1929-1979, Zaragoza, Librería General, 1980.

Pérez Minik Domingo, Facción surrealista española de Tenerife, Barcelona, Tusquets, 1975.

Personneaux Conesa Luce, «En busca del surrealismo perdido», Iris, Montpellier, no 4, 1983, pp. 167-179.

- «El surrealismo en Espańa: espejismos y escamoteos», Actas del VIII Congreso Internacional de Hispanistas, Madrid, Istmo, 1986, pp. 447-454.

Pont Jaume, El Postismo, un movimiento estético-literario de vanguardia, Barcelona, Llibres del mall, 1987.

Prados Emilio, Textos surrealistas, compilación de Patricio Hernández, Málaga, Centro Cultural de la Generación del 27, 1990.

Río Ángel del, "La poesía surrealista de Vicente Aleixandre», Revista Hispánica Moderna, Nueva York, Tomo II, no 1, octubre de 1935, pp. 21-23.

Rolland de Reneville A., "La poesía de Jules Supervielle», Ínsula, Madrid, no 30, 15 de junio de 1948, p. 8.

Salinas Pedro, «Vicente Aleixandre, entre la destrucción o el amor», Índice Literario, Madrid, diciembre de 1935, en Literatura española. Siglo XX, Madrid, Alianza Editorial, 1980, pp. 204-212, 1ªed. 1970.

Sánchez Robayna Andrés (ed.), Canarias: las vanguardias históricas, Santa Cruz de Tenerife, Centro Atlántico de Arte Moderno y Gobierno de Canarias, 1992.

Santos Torroella Rafael, «Genio y figura del surrealismo. Anécdota y balance de una subversión», Cobalto, Barcelona, II, 1948, 5-15.

Soria Olmedo Andrés, Vanguardismo y crítica literaria en España, Madrid, Istmo, 1988.

Turia, Teruel, no 24-25, «Dossier Surrealismo», 1993. 


\section{LA CRÍTICA AL SURREALISMO EN ESPAÑA}

Torre Guillermo de, Literaturas europeas de vanguardia, Madrid, Caro Raggio, 1925.

- Historia de las literaturas de vanguardia, Madrid, Guadarrama, 1965.

Urogallo, El, Madrid, V, no 29-30, no dedicado al surrealismo, septiembre-octubre de 1974.

Vela Fernando, «El suprarrealismo», Revista de Occidente, Madrid, no 18, octubre de 1924, pp. 419-423.

Viejo Topo, El, «Surrealismo», no 18, marzo de 1978, pp. 33-44.

Sin Firma, "Transeúnte central, por Miguel Labordeta», Espadaña, León, no 46, 1950 . 
